A grazing model for simulating the impact of historical land management decisions in sensitive landscapes: Model design and validation

Amanda M. Thomson, I an A. Simpson

Environmental Modelling \& Software, August 2006, volume 21, issue 8, pages: 1096-1113

http:/ / dx.doi.org/ 10.1016/ i.envsoft.2005.05.008 


\title{
A grazing model for simulating the impact of historical land management decisions in sensitive landscapes: Model design and validation
}

\author{
Amanda M. Thomson, I an A. Simpson \\ School of Biological and Environmental Sciences, University of \\ Stirling, Stirling FK9 4LA, Scotland, UK
}

\begin{abstract}
This paper reports the construction and testing of a historical environmental simulation model, Búmodel (bú: Icelandic - farm estate or enterprise). The model permits the investigation of historical grazing management under variable environmental conditions in Iceland through the prediction of spatial and temporal patterns of vegetation biomass and utilisation. Input parameters of the model are environmental, livestock and management variables from historical and archaeological sources. Process sub-models were constructed using contemporary I celandic data. Validation of the model was based on an independent, published grazing experiment and demonstrated that Búmodel-predicted utilisable biomass values and biomass intake values fall within G1 standard deviation of observed values.

Búmodel provides a validated representation of linkages between environmental and management elements in a historical grazing system. It incorporates key issues of spatial and temporal scale, data quality, model validation and the inherent stochasticity of landscape change over historical periods. In doing so, it enables researchers interested in past landscapes to investigate the flexibility of the historical I celandic grazing systems within the constraints of climate and vegetation cover, and provides a framework and methodology that can be applied to other historical extensive livestock-based agricultural systems. Access to the model is available at http://www.sbes.stir.ac.uk/research/environmental_modelling/.
\end{abstract}

Keywords: Spatio-temporal model; Historical landscapes; Grazing management; Iceland; Domestic livestock; Utilisation; Validation

\section{Introduction}

\subsection{Context}

The majority of landscapes today have been affected in some way by long-term human interaction with the natural environment, notably through 
agriculture. Grazing by domestic livestock is one of the primary means by which humans have modified landscapes in temperate regions of the world and is still dominant in areas at high altitudes and latitudes, where other forms of agriculture are restricted. In these locations, where environmental conditions for human subsistence are marginal and landscapes are sensitive to change, improper grazing management can lead to vegetation degradation, soil erosion and unsustainable communities (Simpson et al., 2001; Blaikie and Brookfield, 1987). However, even within a simple pastoral agricultural system a wide range of management strategies are possible (Hill et al., 2003; Hajkowicz et al., 2005). These strategies can initiate, exacerbate or ameliorate vegetation degradation by affecting two key elements: the amount of grazeable vegetation that is available, and the amount that is consumed by domestic livestock.

One little understood aspect of the relationship between grazing activity and land degradation is the historical dimension, which can provide a longterm temporal perspective on issues of contemporary land use sustainability. There is evidence for early grazing land management systems that have contributed to the initiation and reinforcement of patterns of land degradation, as well as successful land management strategies where vegetation and soil quality were sustained over long periods (Netting, 1996; Melville, 1998; Amorosi et al., 1998). To address issues of historical grazing strategies, associated land management decisions and their long-term implications, a wide range of interrelated contributory factors and outcomes need to be considered. Environmental simulation modelling can provide a key methodology for exploring land management strategies under changing historical climate, landscape and social conditions (Gross et al., 2003). There have, however, only been limited attempts to model land management practices in historical contexts, largely because of difficulties in obtaining suitable data for parameterisation and model validation (Simpson et al., 2002; Amorosi et al., 1998). Furthermore, contemporary environmental simulation models currently available for similar grazing situations are generally unsuitable for application in high latitudes and altitudes. Such models have primarily been constructed for semi-arid areas (Pickup, 1994; Foy et al., 1999; Hahn et al., 2005), and/or tend to require extensive parameterisation at a level of detail that is not available in historical contexts (Armstrong et al., 1997a).

\subsection{Objectives}

Our general research aim is to investigate the role of historical farm management decisions in controlling the utilisation of grazing resources by domestic livestock under variable environmental conditions, and the impact that these decisions have upon early farm viability and land degradation, using environmental simulation modelling. The focus for these investigations is I celand, as an example of a place where the contemporary landscape has been extensively modified by grazing in the past (Friðriksson, 1972; Arnalds 
et al., 1987, 2001; Simpson et al., 2001). Here, there has been extensive vegetation degradation and soil erosion in the last 1100 years. Explanations of the causes of this degradation have focussed on both environmental factors (highly variable climate, easily erodible soils) and human factors (principally over-grazing and the removal of the lowland birch forests) (5orarinsson, 1944; Simpson et al., 2001; Olafsdóttir and Guðmundsson, 2002). The country acts as a natural laboratory for the investigation of human-environmental impacts because of the relatively short period of human settlement (post9th century AD) and excellent environmental, archaeological and documentary records through to the widespread introduction of modern farming techniques

c. 1900 AD. Analyses of historic grazing patterns are crucial to understanding the causes of over-grazing and the sensitivity of I celandic landscapes.

To achieve the general research aim, initially in an Icelandic context, requires the development of an historical environmental simulation model. The objective of this paper is therefore to report on the design, construction and testing of such a model. In doing so important issues, essential to the development of valid historical environmental simulation models, are considered. These include spatial and temporal scale, data quality, model validation and the inherent stochasticity of landscape change over historical periods. Applications of the validated model presented in this paper are considered in a second paper (Thomson and Simpson, in press).

\section{Model design and construction}

The historical environmental simulation model is required to predict spatial and temporal patterns of vegetation biomass and utilisation with a view to allowing comment on vegetation degradation, farm viability and sustainability in the pre-modern period (pre-1900 AD) in Iceland. To achieve this, it is necessary to predict the seasonal changes in standing herbage, the relative nutritional value of the most commonly grazed vegetation communities and the fodder requirements of livestock at different times of the year. A simulation model linking the inputs and processes in the Icelandic grazing system has been constructed (Fig. 1). This model is called Búmodel, bú meaning a farm estate or farming enterprise in I celandic. The model operates in the MS Excel spreadsheet package, with additional programming in Visual Basic for Applications, and produces results that can be displayed in a geographic information system (GIS). The model was run on a Pentium II processor personal computer: a single run took $<1$ min and a set of 20 simulation runs for large farm landscapes (400-500 cells) took around 4-5h.

The required historical applications of the model make it necessary to define the set of exogenous variables in such a way that they can be derived for the historic past using archaeological, environmental and documentary sources. The data quality and the aim of modelling seasonal change dictates a monthly time 


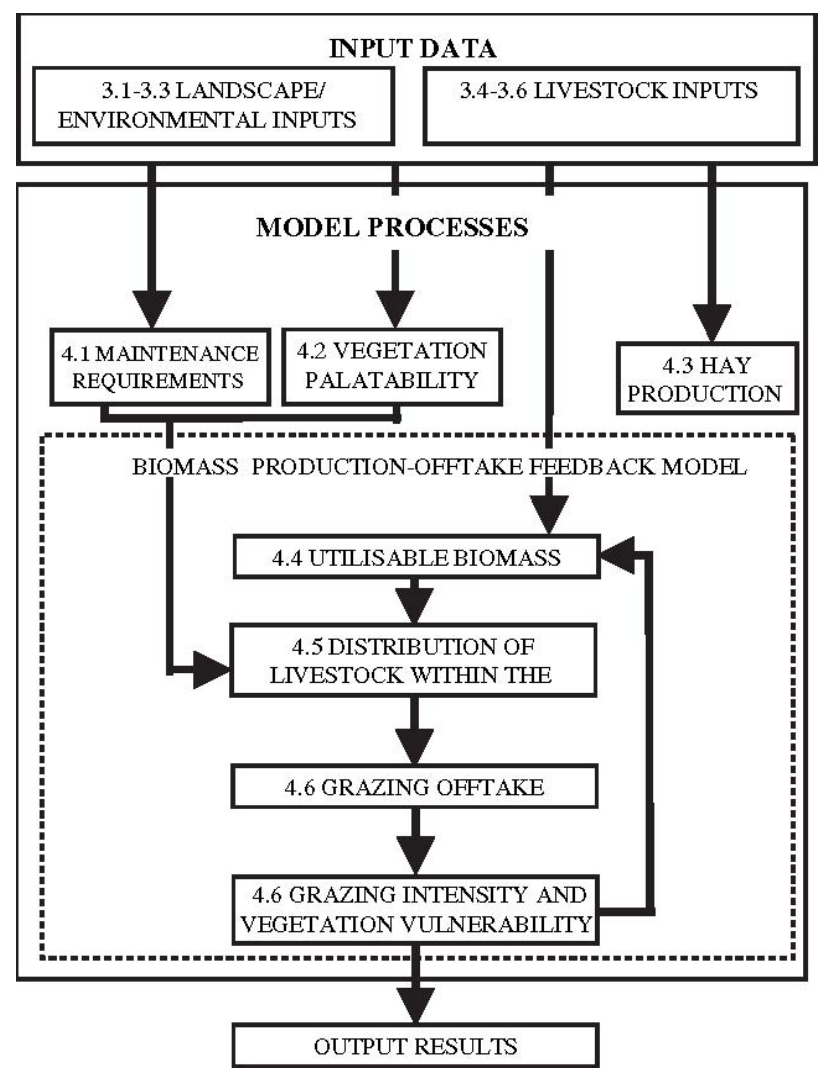

Fig. 1. Structure of Búmodel.

scale and a spatial scale at the vegetation community level (c. 1-1000 ha). The constructed model runs on a single-year basis, in order to restrict the set of potential management choices to manageable levels.

The availability of data is crucial in model construction, and has driven the overall design of Búmodel. Processes are simulated in separate sub-models which combine to make the overall model (labelled in Fig. 1). Búmodel is parameterised with both historical and contemporary data. Model inputs are derived from historical documentary sources or estimated indirectly using evidence from archaeology, palynology and soil science. The model subsystems have been developed using contemporary Icelandic agricultural research with additional information drawn from research in other sub-arctic regions. Collaboration with Icelandic agricultural scientists has ensured that the most appropriate data has been used, and that the model components and structure are reasonable. As some ecosystem parameters, such as vegetation production and community composition are highly variable, these parameters were incorporated as stochastic elements. The same set of environmental and management inputs can result in multiple outcomes, due to the inherent variability of the system embodied in the model. 


\section{Model inputs}

\subsection{Vegetation composition}

A classification of eight vegetation categories was used to map the spatial distribution of vegetation within the grazing area. This classification was synthesised from the published Icelandic literature (Steindórsson, 1980; Thorsteinsson, 1980a; Hallsdóttir, 1987; Magnússon and Magnússon, 1990, 1992; Thorsteinsson and Arnalds, 1992; Gísladóttir, 1998) and fieldwork by the authors (Thomson, 2003). It was based upon grazeable vegetation, rather than botanical composition per se. For application to past landscapes, the vegetation classification had to be simple enough that the past spatial distribution of vegetation could be justifiably inferred from the environmental and historical evidence, while still representing vegetation diversity. The model accepts vegetation input as a matrix of vegetation areas within a grid of $500 \times 500 \mathrm{~m}$ cells covering the grazing landscape.

The grazeable vegetation classification consists of: hayfield, grassy heath, dwarf shrub heath, moss heath, bog/mire, riverine vegetation, birch woodland and sparsely vegetated land. The vegetation communities are composed of six plant types: grasses, sedges and rushes, woody plants, dicot herbs, mosses and lichens, ferns and horsetails. These communities were defined in terms of the relative coverage of each plant type within a range of values, compared to the total vegetation cover in a unit area (Table 1 ). For each vegetation community, plant type 'allocation' is randomised within its cover range using a uniform probability distribution function:

$$
\begin{aligned}
\text { Plant type cover allocation }= & z \text { (upper limit }- \text { lower limit }) \\
& + \text { lower limit }
\end{aligned}
$$

where $z$ is a uniform randomly generated number greater than or equal to 0 and less than 1 . This produced heterogeneous vegetation communities of the same category within the wider landscape. In addition, sparsely vegetated land was defined as having bare ground comprising more than $70 \%$ of the ground cover.

It is assumed that the vegetation categories in the present (at the scale of this study) are analogous to those in the past. Palynological evidence indicates that there have been no major plant species extinctions or introductions during the historical period (Hallsdóttir, 1987), and that the ecological disruption caused by the introduction of livestock grazing took place in the ninth and tenth centuries $A D$, immediately post-settlement. The Icelandic biota responds quickly to change, as can be seen in areas where grazing has been removed, or in the colonisation of volcanic areas (Fridriksson, 1975). Therefore, it can be assumed that any extensive modification of the vegetation occurred in the early 
Table 1 Búmodel vegetation community composition

Table 1

Búmodel vegetation community composition

\begin{tabular}{|c|c|c|c|c|c|c|c|c|}
\hline $\begin{array}{l}\text { Vegetation } \\
\text { community }\end{array}$ & $\begin{array}{l}\text { Grass } \\
(\%)\end{array}$ & $\begin{array}{l}\text { Sedges and } \\
\text { rushes }(\%)\end{array}$ & $\begin{array}{l}\text { Woody } \\
\text { species (\%) }\end{array}$ & $\begin{array}{l}\text { Dicot } \\
\text { herbs }(\%)\end{array}$ & $\begin{array}{l}\text { Moss and } \\
\text { lichen }(\%)\end{array}$ & $\begin{array}{l}\text { Horsetails } \\
\text { and ferns (\%) }\end{array}$ & $\begin{array}{l}\text { Bare } \\
\text { ground }(\%)\end{array}$ & Additional definitions \\
\hline Hayfield & $50-95$ & - & - & $10-20$ & $0-15$ & - & - & $\begin{array}{l}\text { Grasses and herbs are }>85 \% \text { of } \\
\text { total cover }\end{array}$ \\
\hline Grassy heath & $20-50$ & $0-20$ & $0-20$ & $1-30$ & $1-40$ & $0-5$ & $0-15$ & $\begin{array}{l}\text { Grasses and herbs make up } \\
50-80 \% \text { of total cover }\end{array}$ \\
\hline $\begin{array}{l}\text { Dwarf } \\
\text { shrub heath }\end{array}$ & $5-25$ & $0-20$ & $40-80$ & $5-20$ & $10-40$ & $0-15$ & $0-20$ & $\begin{array}{l}\text { Woody species are dominant, } \\
>40 \% \text { of total cover }\end{array}$ \\
\hline Moss heath & $5-20$ & $5-15$ & $5-25$ & $5-20$ & $50-95$ & $0-5$ & $5-50$ & Mosses and lichens are $>50 \%$ of cover \\
\hline Bog or mire & $0-20$ & $15-50$ & $0-30$ & $0-20$ & $5-40$ & $5-20$ & $0-15$ & $\begin{array}{l}\text { Sedges and rushes are dominant, } \\
\text { ground is permanently or periodically } \\
\text { waterlogged }\end{array}$ \\
\hline $\begin{array}{l}\text { Riverine } \\
\text { vegetation }\end{array}$ & $10-40$ & $0-20$ & $0-30$ & $10-45$ & $0-30$ & $0-20$ & $0-10$ & $\begin{array}{l}\text { Herbs must be one of the } \\
\text { dominant plant types }\end{array}$ \\
\hline $\begin{array}{l}\text { Birch } \\
\text { woodland }\end{array}$ & $0-30$ & $0-10$ & $20-40$ & $0-15$ & $15-40$ & $0-10$ & $0-15$ & $\begin{array}{l}\text { Birch trees must be present, but } \\
\text { no one plant type need have dominance }\end{array}$ \\
\hline $\begin{array}{l}\text { Sparsely } \\
\quad \text { vegetated land }\end{array}$ & $0-15$ & $0-10$ & $0-10$ & $0-10$ & $0-15$ & $0-10$ & $70-100$ & More than $70 \%$ bare ground cover \\
\hline
\end{tabular}

As vegetation can consist of several layers, the total vegetation cover can total more than $100 \%$. The percentages listed above are those of the plant types compared to the total vegetation cover (apart from bare ground, which is a percentage of the actual ground surface area).

centuries of human occupation (Buckland et al., 1991), and that during most of the historic period the vegetation communities were similar to those found in the modern period (Thorsteinsson and Arnalds, 1992).

\subsection{Land use categories}

The grazing area represented within the model can be divided into three zones of activity: the tún or infield area, the lowland outfield area, and the rangeland. The infield area was the only area of cultivated land, being a few hectares in extent, and was used principally for hay production. In the model it is assumed to be inaccessible to grazing throughout the year. The outfield was the privately owned uncultivated farmland, used for the grazing of livestock and some hay production. The rangeland was the extensive summer grazing area beyond the limits of the outfield, which could consist of anything from relatively productive heathland to barren desert (Arnalds et al., 2001). The rangeland was usually, but not always, communally owned, and its limits were generally defined by natural barriers such as rivers or glaciers. Each grid cell in the model is defined as outfield or rangeland: the infield area is subsumed within the outfield zone as being equivalent to the area covered by the hayfield vegetation community.

\subsection{Climate scenarios}

Generalised climatic scenarios are used in the model, based upon air temperature, which is the dominant climatic control upon vegetation growth in Iceland (moisture availability is not assumed to be a limiting factor) (Ogilvie, 1984a; Bergpórsson et al., 1987). Four climatic scenarios (baseline, 
warm, cold and extreme cold) (Fig. 2) are defined following the example of Bergpórsson et al. (1987). The scenarios are based upon mean monthly temperature from the long series of meteorological observations (1845present) at Stykkishólmur on the west coast (Icelandic Meteorological Office, 2001). This station record is a good overall predictor of temperature in Iceland (Bergpórsson et al., 1987). According to historical climate analysis (Ogilvie, 1984b) these scenarios represent the range of climatic variability in I celand during the pre-modern period. The scenarios control the starting date and length of the growing season and the production of utilisable biomass within the growing season. They also affect the fodder requirements of livestock.

\subsection{Flock size and composition}

The Icelandic agricultural system in the pre-modern period was dependent upon livestock, principally sheep, cattle and horses. The model focuses on sheep numbers, as they were the most numerous livestock in pre-modern I celandic agriculture (Friðriksson, 1972). The inclusion of cattle (an important component of the farming economy in the earlier centuries of settlement) would be a priority in any future development of the model.

The model sheep flock is composed of four cohorts: fertile ewes, lambs, immature or barren ewes, and rams or adult wethers (gelded rams). The size of each cohort is explicitly specified in the model. These parameter 

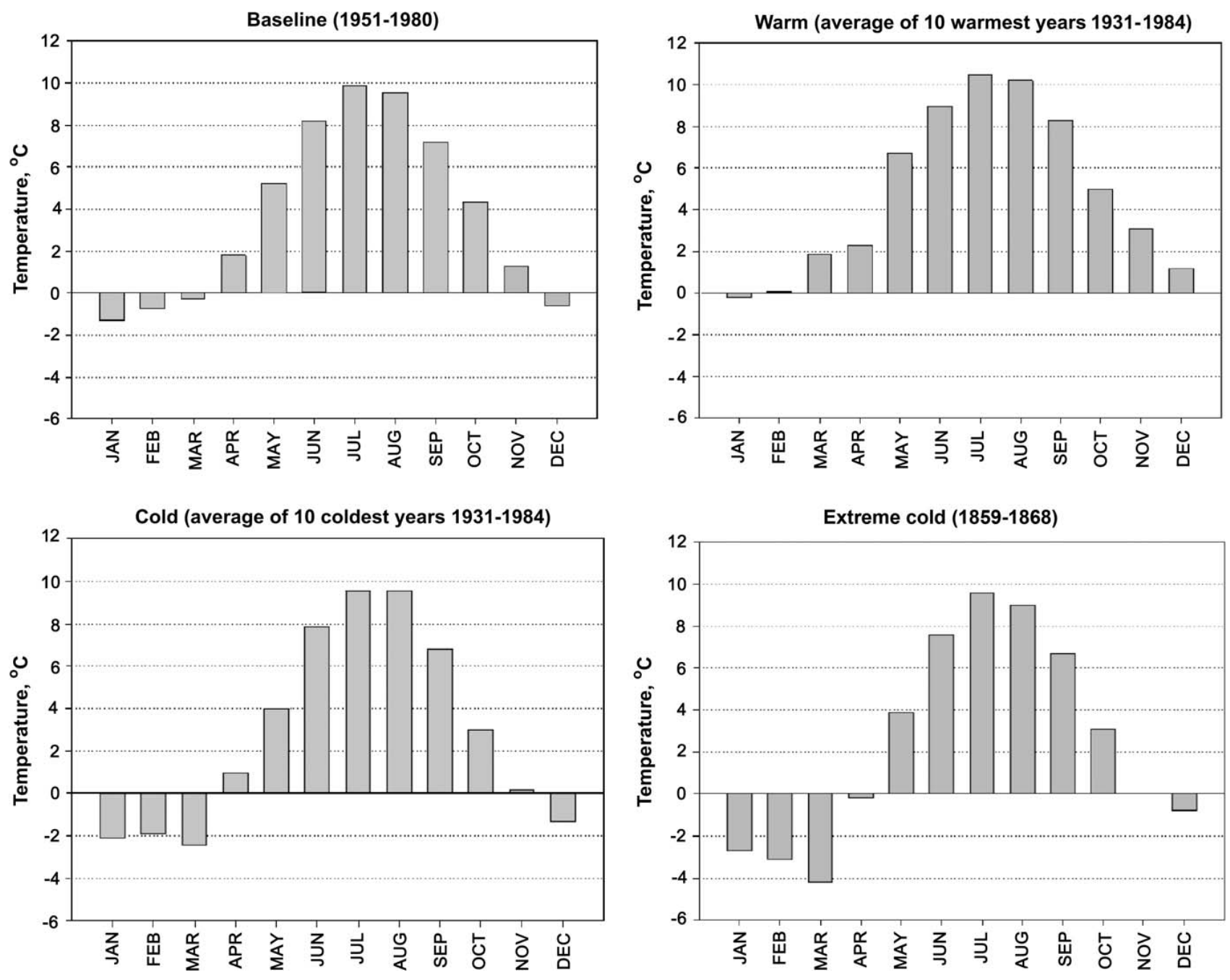

Fig. 2. The four Búmodel climatic scenarios.

values can be estimated from historical records and archaeological evidence. Búmodel assumes that lambs are born at the beginning of May (the lamb cohort represents live births). The size of the lamb and immature/barren ewe cohorts can be adjusted by slaughter at the end of September. As the model only runs for a single year natural mortality is not included in the model.

\subsection{Livestock body weight}

Live body weight is used to calculate the basic nutritional requirements (maintenance) of an animal. The average weights of fertile ewes, immature/barren ewes and rams/wethers can be specified within the model, within the range of 20 and $100 \mathrm{~kg}$. These weights are assumed to remain constant, although a weight loss of up to $40 \%$ may be specified in winter. Lamb live body weight is calculated from the fertile ewe weight in the previous autumn, $W$, and the age of the lamb in days, $T_{L}$ 


$$
\text { Lamb live weight }=0.00312 T_{\mathrm{L}}+0.0783 \mathrm{~W} \text {. }
$$

This equation has been derived from the Macaulay Institute's Hill Grazing Management Model (Armstrong et al., 1997b), taking account of the slower growth rates of Icelandic sheep compared with UK animals (evident from slaughter weight records).

\subsection{Livestock distribution}

Livestock are distributed within the modelled landscape on a monthly basis. Each livestock cohort can be assigned to either a land use category or to the 'byre' (for the winter months when livestock were kept indoors and fed hay). This distribution governs the grazing pressure within each land use category and the fodder requirements of livestock.

4. Process sub-models

\subsection{Maintenance requirements sub-model}

The maintenance feed requirements of individual animals in each livestock cohort are calculated within this sub-model (Fig. 3), based upon live body weight and grazing conditions. The sub-model output is used to predict the amount of vegetation that will be consumed by grazing. Outputs are described in feed units (fu), with 1 feed unit equivalent to 13-14 MJ metabolizable energy (Thorsteinsson and Thorgeirsson, 1989). The energy values of Icelandic vegetation communities range from 0.455 to $0.667 \mathrm{fu} \mathrm{kg}$ DM (Thorsteinsson, 1980c). Maintenance fodder requirements are calculated from the live body weight, based upon research derived from Breirem in Olafsson (1980). Requirements can vary within a range of values, given by the equations:

$$
Y_{\mathrm{UP}}=0.0084 x+0.1737,
$$

for the upper range limit, and

$$
Y_{\text {LOW }}=0.0071 x+0.1383,
$$




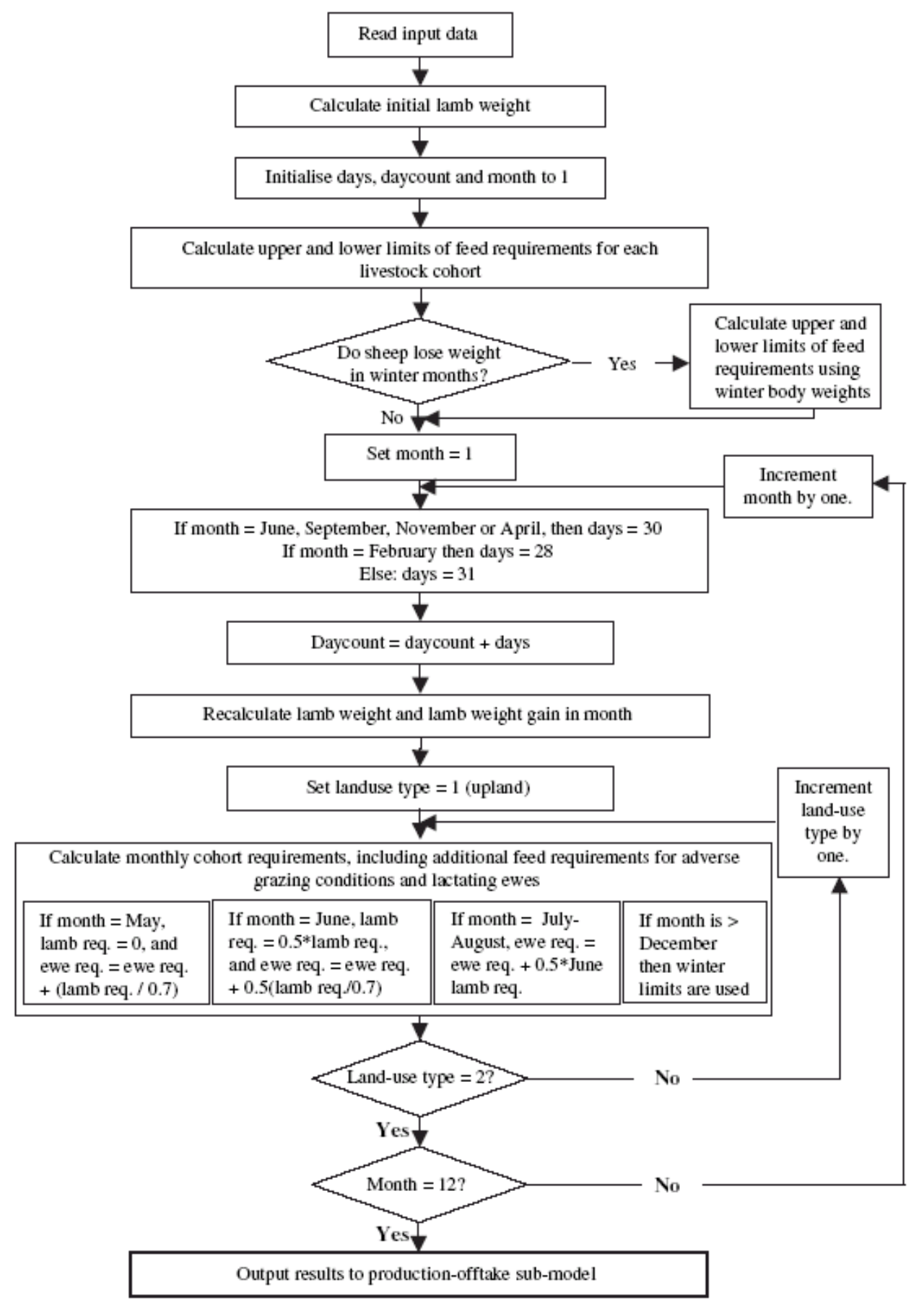

Fig. 3. Maintenance requirements sub-model structure.

for the lower range limit, where $Y$ is the feed unit maintenance requirement and $x$ is live weight in kilograms. In the maintenance sub-model the individual feed requirement of each sheep cohort is randomised between the upper and lower maintenance limits 
Individual feed requirement

$$
=z(\text { upper limit }- \text { lower limit })+\text { lower limit, }
$$

where $z$ is a randomly generated number greater than or equal to 0 and less than 1.

Lambs have an additional fodder requirement for growth. The feed units required for each kilogram of growth increase with age (Table 2). The maintenance requirement of lambs is assumed to increase with body weight at the same rate as it does for adult sheep.

Lambs are assumed to acquire all of their feed requirements from ewes' milk for their first six weeks of life, after which they are weaned. Thus the feed requirements of ewes will also increase while they are lactating. Only $70 \%$ of the feed units consumed by the mother for milk production are passed on to the lamb through the milk (Guðmundsson, pers. comm.). In the pre-modern period milking of the ewes would have continued after weaning, maintaining the increased fodder requirement. Búmodel assumes that lactation declines over the summer months, before ceasing entirely in August.

Maintenance requirements are greater for grazing than byred livestock, and are affected by the location, type and condition of the available pasture. The initial maintenance requirement calculations are adjusted to take account of the additional energy requirements of sheep living out of doors (Table 3 ). In Búmodel the grazing conditions can be represented by the land use category and the climatic scenario in combination. If the livestock are kept and fed indoors, then no adjustment of the feed requirements is necessary.

Table 2 Maintenance feed requirements for sheep (Breirem in Olafsson, 1980)

Maintenance foed requirements for sheep (Breirem in Ólafsson, 1980)

\begin{tabular}{ll}
\hline Live weight of ewes $(\mathrm{kg})$ & Feed units/day \\
\hline $30(25-35)$ & $0.34-0.41$ \\
$40(35-45)$ & $0.42-0.51$ \\
$50(45-55)$ & $0.50-0.60$ \\
$60(55-65)$ & $0.57-0.69$ \\
$70(65-75)$ & $0.64-0.77$ \\
$80(75-85)$ & $0.71-0.85$ \\
$90(85-95)$ & $0.77-0.93$ \\
$100(95-105)$ & $0.84-1.00$ \\
\hline
\end{tabular}

The feed requirements are based on that of an ewe weighing $50 \mathrm{~kg}$. The energy requirements of heavier and lighter animals are calculated from the body weight, using a factor of 0.75 . 
Table 3 Adjustment in maintenance requirement for different grazing conditions (from Guðmundsson, 1991)

\begin{tabular}{llc}
\hline $\begin{array}{l}\text { Pasture } \\
\text { class }\end{array}$ & Grazing conditions & $\begin{array}{l}\text { Increase in } \\
\text { maintenance } \\
\text { requirements (\%) }\end{array}$ \\
\hline 1 & $\begin{array}{l}\text { Good cultivated land, good weather } \\
\text { Average cultivated land or good }\end{array}$ & 10 \\
2 & $\begin{array}{l}\text { native pasture } \\
\text { Heavily grazed cultivated land or }\end{array}$ & 50 \\
3 & $\begin{array}{l}\text { average native pasture } \\
\text { Mountainous rangeland, long } \\
\text { grazing times }\end{array}$ & 75 \\
5 & $\begin{array}{l}\text { Poor mountainous rangeland, } \\
\text { in bad weather }\end{array}$ & $<100$ \\
\hline
\end{tabular}

\subsection{Vegetation palatability and plant preferences sub-model}

The selection of certain areas for grazing is governed by their accessibility, and the quantity and palatability of the plants that grow in those areas. Within Búmodel the accessibility of the grazing area is controlled by the GIS component and the quantity of vegetation is calculated within the utilisable biomass sub-model, but a method of representing the palatability of vegetation to livestock is also required.

Freely-grazing livestock in a heterogeneous pasture show a high degree of preference for grazing certain plant species, at the expense of others. Búmodel combines information on plant digestibility and livestock plant preferences into a measure of palatability. Research on the vegetation preferences of livestock conclude that the same species are grazed across a range of communities (Thorsteinsson, 1964; Thorsteinsson and Olafsson, 1967; Olafsson, 1973; Magnússon and Magnússon, 1990, 1992; Thórhallsdóttir and Thorsteinsson, 1993). These species are: Festuca rubra, Calamagrostis neglecta, Agrostis spp., Poa spp., Carex bigelowii, Salix callicarpea, Polygonum viviparum, Galium spp., and Equisetum spp.

The seasonal changes in plant selection also follow a consistent pattern (Thórhallsdóttir and Thorsteinsson, 1993). During the summer livestock prefer grasses above other plant types, as they are highly digestible. With maturity the digestibility of grasses declines. As a consequence of this decline, grasses are less preferred by livestock in winter, and tend to be replaced in the diet by evergreen woody species (Olafsson, 1973; Thorsteinsson, 1980a). Woody plants maintain their digestibility year-round, and also retain green leaves in winter, which are more attractive to grazing animals. It should be noted that the Salix species found in Iceland ( $S$. callicarpea, Salix herbacea, Salix lanata and Salix phylicifolia) and Betula pubescens also seem to be highly palatable to 
sheep in the summer. The botanical composition of the diet will vary according to the vegetation community and the variety of plant species that are available to grazing livestock. Some plants are only available for grazing during the summer and changes in dietary composition have been observed at high stocking rates where botanical diversity is reduced (Grant et al., 1976; Magnússon and Magnússon, 1992).

In Búmodel relative palatability values are assigned to each plant type within the vegetation communities (Fig. 4). These palatability values are defined on an ordinal scale of low, medium and high palatability (Table 4). Plant species within each plant type do not necessarily have the same palatability, but species commonly found in the same vegetation community are usually similarly palatable. Palatability may change between seasons, so a two-season split, summer and winter, is used in Búmodel.

A palatability score is calculated for each cell based on the palatability rating and cover of each plant type within the cell. Vegetation communities that consist of a limited number of species have a narrow range of palatability scores. The communities with more variability in their botanical composition, such as bogs, can have a wide range of palatability scores. The palatability score is used when the model distributes livestock within the landscape.

\subsection{Hay production sub-model}

A simple model was designed to calculate hay yield, based on work by Bergpórsson et al. (1987). This model expresses the mean hay yield on improved grassland as a function of temperature and nitrogen fertiliser application. The availability of nitrogen fertiliser for hay fields in the premodern period was largely dependent upon the availability of manure. This, in turn, was dependent on the number of animals housed indoors through the previous winter. During the time they were kept inside the livestock were fed on hay, although some outdoor grazing may also have taken place.

Bergpórsson et al. (1987) estimated that $100 \mathrm{~kg}$ of hay contains approximately $1.8 \mathrm{~kg}$ of nitrogen, but the manure that is produced from feeding livestock with this hay is $0.8-0.9 \mathrm{~kg}$ of effective nitrogen fertiliser (if the manure is well preserved). The amount of effective nitrogen fertiliser produced by livestock wintered indoors can be estimated from the quantity of hay that these livestock consume. If the hayfield area is also known, then the potential application of nitrogen per hectare can be calculated.

A regression equation was calculated based on data from 1901 to 1940 (Bergpórsson et al., 1987), in the period before the widespread use of artificial fertilisers. Estimated nitrogen applications in this period were 


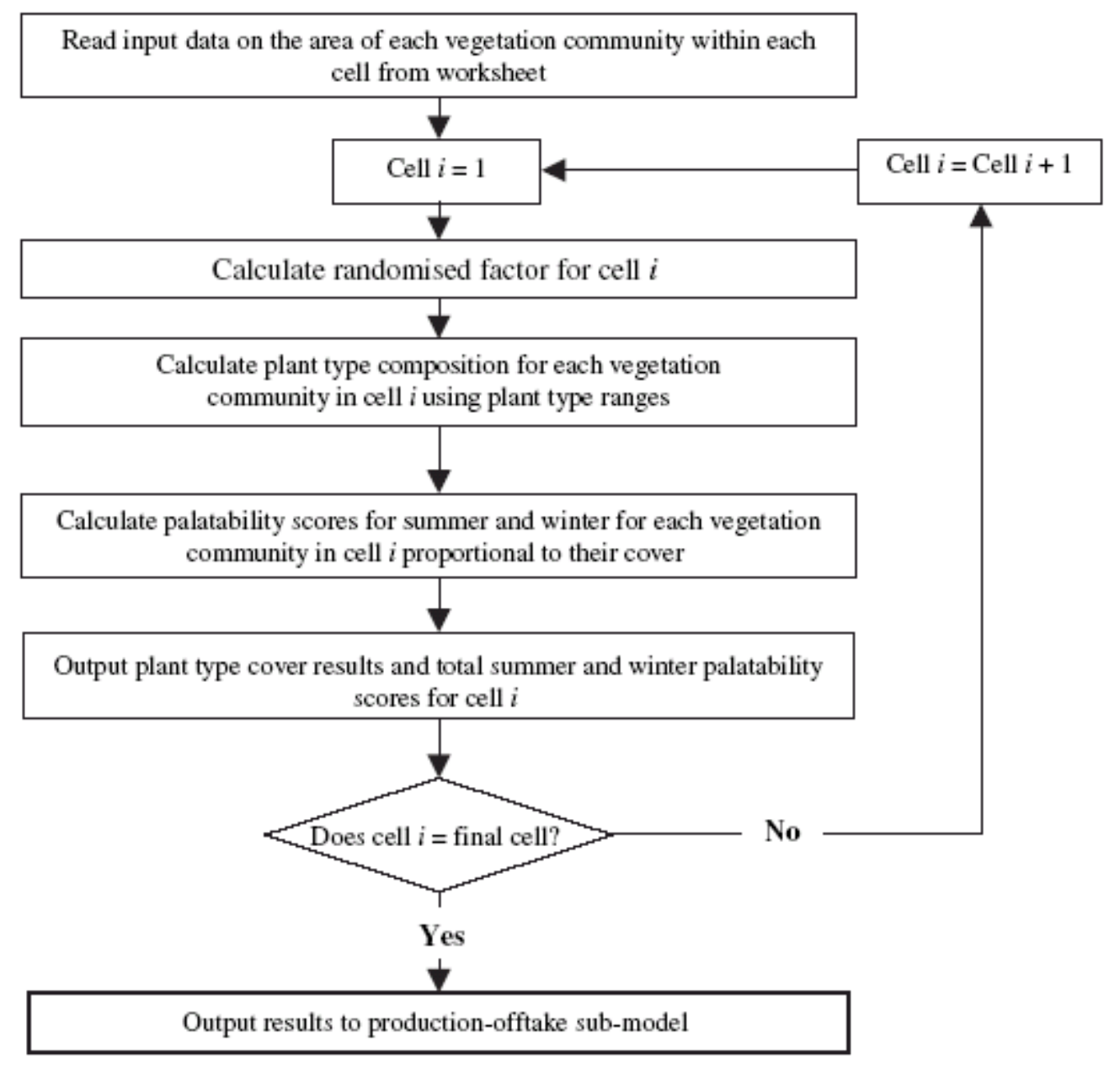

Fig. 4. The structure of the plant preferences sub-model.

Table 4 Palatability values of plant types in each Búmodel vegetation community

\begin{tabular}{|c|c|c|c|c|c|c|}
\hline Vegetation community & Grasses & $\begin{array}{l}\text { Sedges and } \\
\text { rushes }\end{array}$ & Woody species & Herbs & $\begin{array}{l}\text { Moss and } \\
\text { lichen }\end{array}$ & $\begin{array}{l}\text { Ferns and } \\
\text { horsetails }\end{array}$ \\
\hline \multicolumn{7}{|c|}{ Palatability of plant types in summer } \\
\hline Grassy heath & High & Medium & Medium & Medium & - & Medium \\
\hline Dwarf shrub heath & High & Low & Low & Medium & - & Medium \\
\hline Moss heath & High & Medium & Low & Medium & - & Medium \\
\hline Bog or mire & High & Medium & Low & Medium & - & Medium \\
\hline Riverine & High & Medium & Medium & High & - & Medium \\
\hline Birch woodland & High & Medium & Medium & High & - & Medium \\
\hline Sparsely vegetated land & High & Low & Low & Medium & - & Medium \\
\hline \multicolumn{7}{|c|}{ Palatability of plant types in winter } \\
\hline Grassy heath & Low & Low & Medium & - & - & Low \\
\hline Dwarf shrub heath & Low & Low & Medium & - & - & Low \\
\hline Moss heath & Low & Low & Low & Low & - & Low \\
\hline Bog or mire & Low & Low & Low & - & - & Low \\
\hline Riverine & Low & Low & Low & Low & - & Low \\
\hline Birch woodland & Low & Low & Medium & - & - & Low \\
\hline Sparsely vegetated land & Low & Low & Low & Low & - & Low \\
\hline
\end{tabular}


below $70 \mathrm{~kg} \mathrm{ha}{ }^{-1}$. The use of best sub-sets regression in MINITAB gave the following linear regression equation:

$$
\begin{aligned}
& Y=-66+226 W+186 S+25.8 N \\
& \left.R^{2}=80.2 \% R^{2} \text { (adj. }\right)=78.5 \%
\end{aligned}
$$

where $\mathrm{Y}$ is the hay yield from improved grassland $\left(\mathrm{kg} \mathrm{ha}^{-1}\right), \mathrm{S}$ is mean summer temperature (May-September) at Stykkishólmur ( C), W is the mean winter temperature (October-April) at Stykkishólmur ( $\mathrm{C}$ ) and $\mathrm{N}$ is the total fertiliser nitrogen $\left(\mathrm{kg} \mathrm{ha}{ }^{-1}\right.$ of improved grassland). As the temperature parameters are calculated from the Stykkishólmur meteorological record in western Iceland, this regression equation is thought to be a reasonable predictor of hay yields in lowland sites in Iceland. The structure of the hay production sub-model is shown in Fig. 5.

\subsection{The utilisable biomass sub-model}

Utilisable biomass (UB) is the term used for the vegetation that is available to grazing livestock; it is defined as the quantity of grazeable vegetation covering a unit of area at any one time, and is expressed as kilograms of dry matter per hectare. UB incorporates all herbaceous plant material above the ground or above the moss/lichen layer within the sward. The UB available at any time depends upon the amount of vegetation growth and decay previous to that time and upon the intensity of grazing.

The production of new utilisable biomass is confined to the growing season, which is defined as the period when the mean four-weekly air temperature is above a base level of $4.4 \mathrm{C}$ (pers. comm. from Borgpór Magnússon and Olafur Dy'rmundsson). The length of the growing season is between four and six months in the south of Iceland (May-October) and three and five months in the north (May-September) (Icelandic Meteorological Office, 2001).

The model makes use of vegetation biomass measurements from the published Icelandic literature and fieldwork undertaken in the summers of 2000 and 2001 in Eyjafjallassveit and Mývatnssveit (RALA, 1978a,b, 1979, 1980, 1981; Thorsteinsson, 1980a; Gísladóttir, 1998; Magnússon et al., 1998, 1999; Thomson, 2003). All of the measurements have been taken from sites that have been subject to grazing, but information from sites with the lightest grazing pressures has been used wherever possible.

The different growth curves of the most common plant species affect the amount of utilisable biomass available from vegetation communities at different times of year. Production adds new material to the utilisable biomass pool, and this material is gradually removed by the processes of senescence and litterfall (in the absence of grazing or mowing). In a subarctic country such as Iceland the growing season is short but summer insolation is high, allowing high growth rates early in the growing season (Archer and Tiezen, 1980; Archibold, 1994). 
Mean monthly utilisable biomass (UB) curves are used within Búmodel to calculate the available utilisable biomass, rather than explicit production and senescence values. The monthly mean UB curves for each vegetation community are calculated from biomass measurements from fieldwork and the published literature, and information on the growth characteristics of the common plant types within that vegetation community (Archer and Tiezen, 1980; Archibold, 1994; Friðriksson and Sigurðsson, 1983; Prock and Ko" rner,

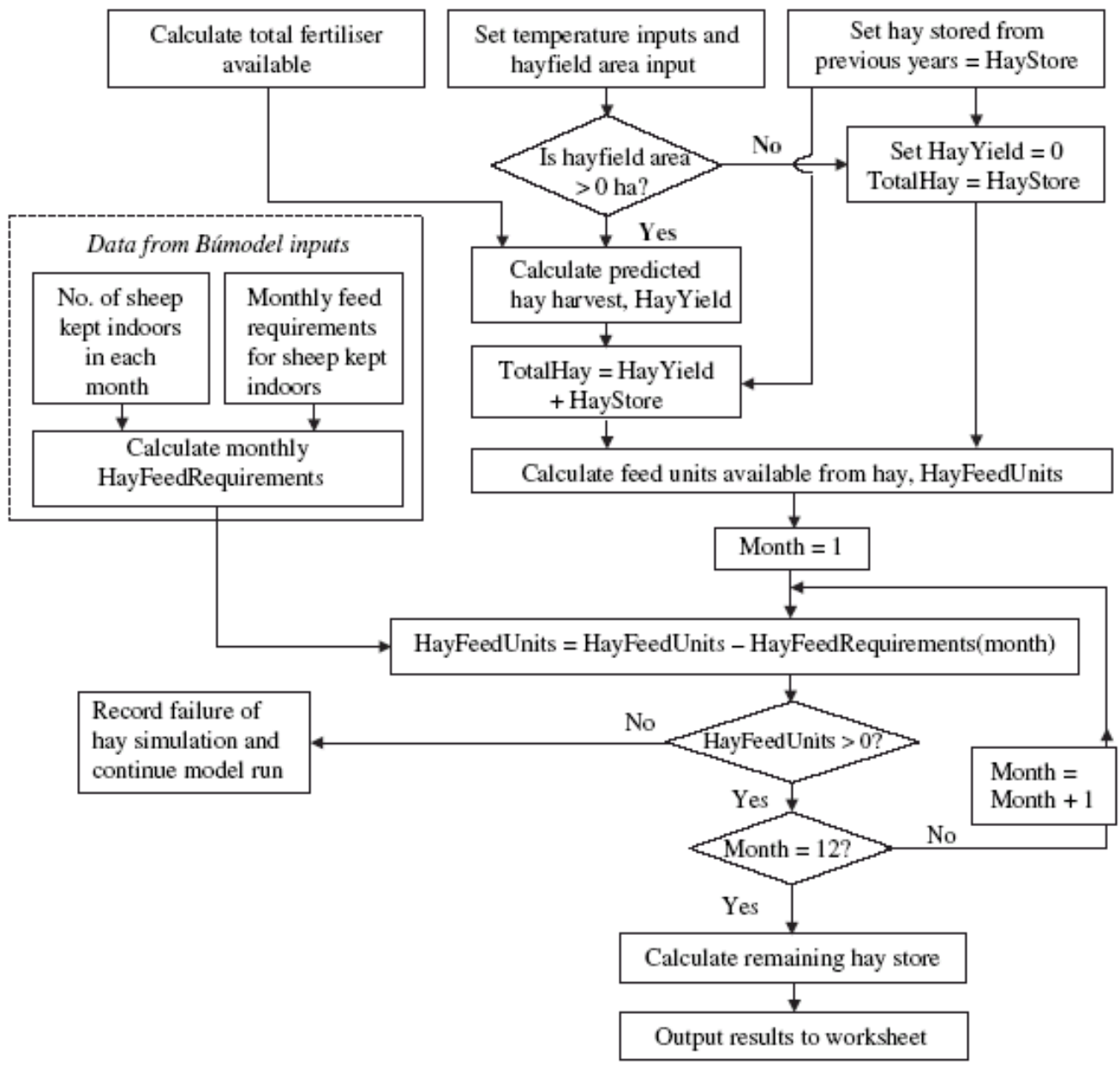

Fig. 5. The structure of the hay yield sub-model.

1996). There can be considerable variability in the quantity of UB available in different patches of the same vegetation community within a relatively small geographical area. In order to accommodate this natural variation in productivity, minimum and maximum UB limits are fitted around the mean biomass curve, and the UB value for a community patch within each cell is selected from within these limits. A value of $+/-55 \%$ of the mean monthly UB was chosen, in order to standardise variability across all vegetation communities. This was based on the mean value for the standard deviations and interquartile ranges as a percentage of the mean and median UB values derived from fieldwork and published literature. 
The mean monthly UB is also affected by the length of the growing season and temperature parameters, represented by the climatic scenario (Table 5). Utilisable biomass is calculated at the beginning of each month in the model run (Fig. 6). In the summer months (AprileSeptember) the UB of each vegetation community in each cell is calculated according to the climate scenario. In winter (October-March) UB is calculated thus:

$$
\mathrm{UB}_{\mathrm{i}}=\left(\text { available } \mathrm{UB}_{\mathrm{i}-1}-\text { consumed } \mathrm{UB}_{\mathrm{i}-1}\right) L_{\mathrm{i}} \text {, }
$$

i being the month, and $L$ being the litterfall rate in that month, calculated from the UB curve as the proportional change in biomass between month i 1 and month $i$. The influence of altitude upon UB production was not considered, although the growing season is shorter at high altitudes (Friðriksson and Sigurðsson, 1983), as botanical composition and the amount of bare ground are assumed to exert a greater influence.

\subsection{Livestock distribution sub-model}

It is assumed that within a spatially diverse landscape, livestock are distributed according to the

Table 5 The influence of the climatic scenario upon the utilisable biomass in Búmodel

\begin{tabular}{|c|c|c|c|c|}
\hline \multirow{2}{*}{$\begin{array}{l}\text { Growing season } \\
\text { parameter }\end{array}$} & I & II & III & IV \\
\hline & $\begin{array}{l}\text { Baseline } \\
\text { scenario }\end{array}$ & $\begin{array}{l}\text { Extreme } \\
\text { cold } \\
\text { scenario }\end{array}$ & $\begin{array}{l}\text { Cold } \\
\text { scenario }\end{array}$ & $\begin{array}{l}\text { Warm } \\
\text { scenario }\end{array}$ \\
\hline Start of growing season & May & June & June & May \\
\hline End of growing season & September & September & September & October \\
\hline Time of peak UB & July & August & August & July \\
\hline $\begin{array}{l}\text { Change in production } \\
\text { relative to baseline } \\
\text { scenario }\end{array}$ & $100 \%$ & $60 \%$ & $80 \%$ & $130 \%$ \\
\hline
\end{tabular}




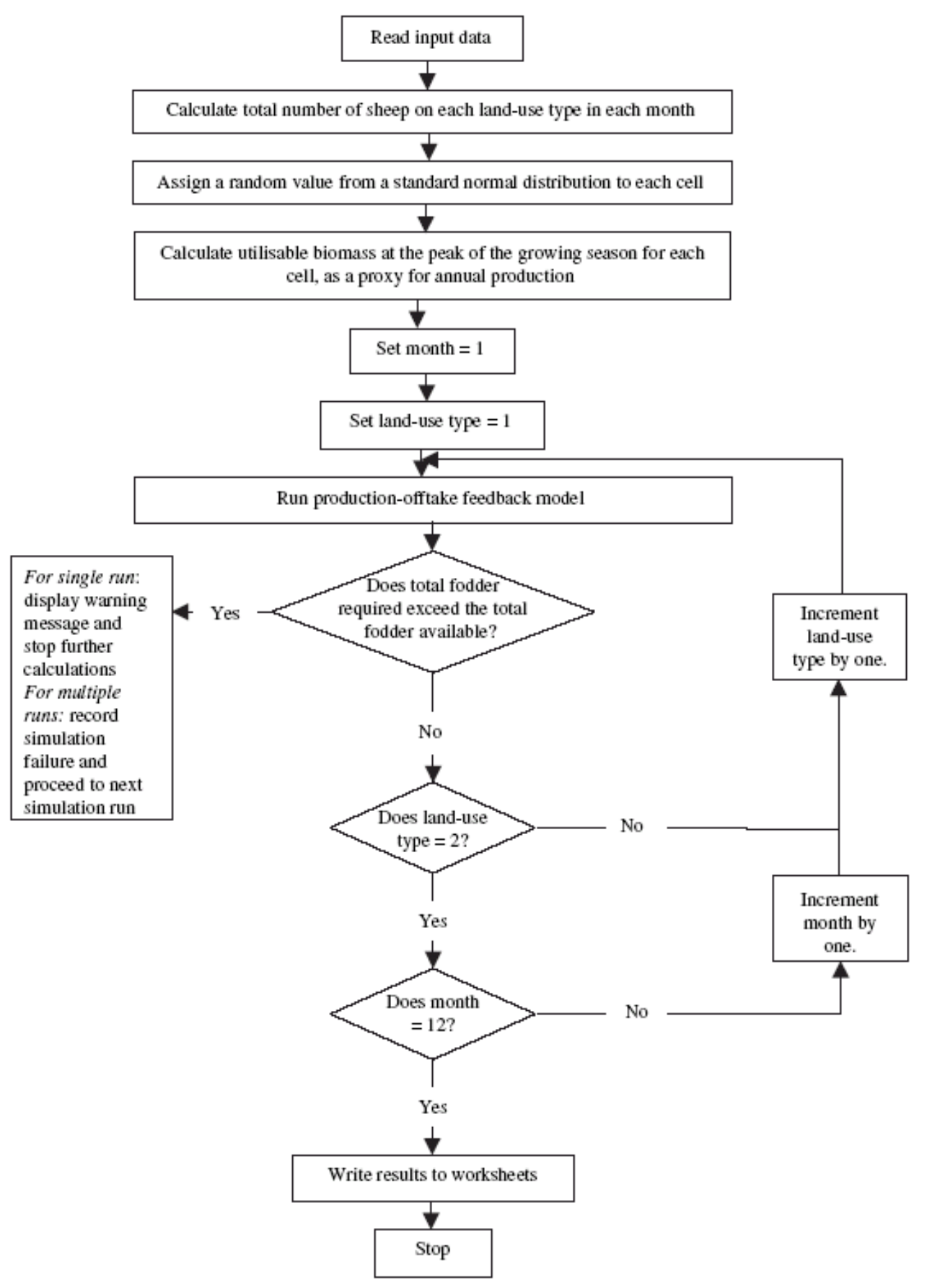

Fig. 6. The structure of the utilisable biomass sub-model.

distribution of the most preferred vegetation communities. This distribution will vary through time as the amount of utilisable biomass (UB) changes through interactions between plant growth, plant death and decomposition (removal from the system), and grazing. The distribution of livestock within a 
single month, $a$, can be expressed in the equation

$$
S_{i}=S_{n} \frac{P_{i} H_{i}}{\sum_{i=0}^{n} P_{n} H_{n}}
$$

where $S_{i}$ is the stocking pressure in cell $i$ in month $a, S_{n}$ is the total number of sheep in all cells $n, P_{i}$ is the palatability score of cell $i, H_{i}$ is the utilisable biomass in cell $i$ in month $a, P_{n}$ is the sum of palatability scores in all cells and $n$ is the sum of all the utilisable biomass in all cells, $n$. This sub-model produces a value for the average monthly livestock density in each cell. It is assumed that livestock could have travelled to any accessible location within the available area within the monthly time scale. The relationship between vegetation distribution and palatability on seasonal sheep distribution is shown in Fig. 7, which also demonstrates how the model results may be displayed in a GIS. Sheep densities are highest on areas of riverine and grassy heath vegetation in the summer, and on areas on dwarf shrub heath vegetation in winter months (Thomson and Simpson, in press). 'Flocking effects' are discounted as the low productivity of I celandic 

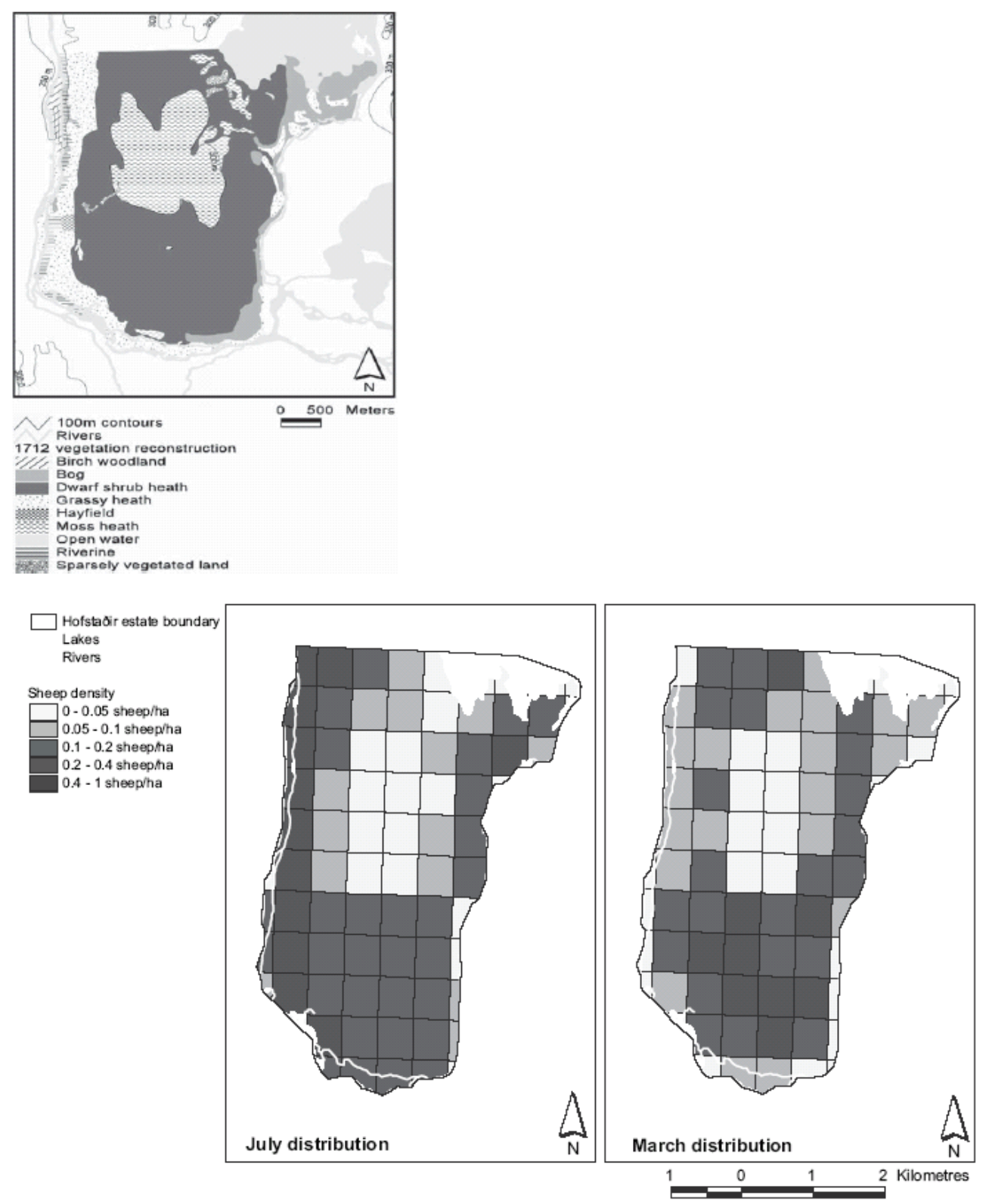

Fig. 7. Example of model output displayed in GIS: 18th century vegetation reconstruction and modelled sheep distribution for summer and winter on the Hofstaðir farm estate, Mývatnssveit, northern Iceland.

pastures leads to the wide dispersal of animals (Arnold and Dudzinski, 1978). The availability of water is not considered a limiting factor to the dispersal of livestock. 


\subsection{Grazing offtake and the biomass production feedback loop}

The total biomass offtake from each cell is calculated on a monthly basis from the individual fodder requirement for the land use category and the density of animals in that cell. Each vegetation community within the cell contributes to the total offtake; the size of the contribution is calculated using the relative palatability of each vegetation community compared with the other vegetation communities available within the cell. The offtake requirement in feed units from each vegetation community is converted into kilograms of dry matter, based upon the feed unit value.

The level of biomass utilisation by livestock may be calculated from the amount of UB that is removed from a cell by grazing. The cumulative utilisation is the sum of all UB removed as a percentage of the peak growing season UB (a proxy for annual production) (Friðriksson, 1972). Overutilisation may be said to occur when utilisation exceeds a certain threshold value, which may vary between vegetation communities (Thorsteinsson, 1980b). A 40\% utilisation threshold is used for the grassy heath, moss heath, riverine, birch woodland and sparsely vegetated communities; a threshold of $15 \%$ for dwarf shrub heath, and a threshold of $35 \%$ for bog/mire (RALA, 1978a,b, 1979, 1980, 1981). Over-utilisation of UB during the growing season impacts upon growth in subsequent months, while overutilisation outside the growing season may impact upon growth in subsequent seasons (although this is not considered in the present version of the model) (Archer and Tiezen, 1980). If these thresholds are exceeded during the growing season then Búmodel reduces the mean UB of a vegetation patch by $20 \%$ in subsequent months (developed from the results of the RALA grazing experiments (RALA, 1978a,b, 1979, 1980, 1981). The structure of this feedback model is shown in Fig. 8.

\section{Model validation}

Búmodel was designed to model management scenarios in a simplified representation of a real landscape, producing a range of possible outputs from a set of input parameters (Hill et al., 2005). There are two output parameters that it is important for Búmodel to represent as accurately as possible: the quantity of grazeable vegetation available to livestock at different times of year and how much of this available fodder the livestock consume. From these variables the extent of grazing utilisation in different parts of the grazing area is calculated. Validation of the entire model can only be partial, due to the historical nature of some of the inputs and the lack of suitable data sets against which Búmodel can be tested. However, it is possible to validate those parts of the model that have been parameterised using contemporary I celandic data. The data set used for validation comes from a grazing experiment undertaken in 1989 in central northern Iceland (Jónsdóttir, 1994). 


\subsection{Sensitivity analysis}

A sensitivity analysis of the principal model parameters was undertaken as part of the validation process (Merritt et al., 2005). Stocking rate and climatic scenario have the greatest effect upon the model outputs. Offtake is greater with higher stocking rates, increasing utilisation of the available biomass. The climatic scenarios affect both the production of utilisable biomass and the feed requirements of livestock, thus having a dual impact upon utilisation. Less utilisable biomass is produced under the cooler climate scenarios, but the feed requirements of livestock are increased, and vice versa under warmer climate scenarios.

Moss heath and sparsely vegetated land are the most sensitive vegetation types in the model. These vegetation types can only support livestock at very low stocking levels (generally less than 0.16 ewes ha ${ }^{-1}$ ), due to their very low levels of utilisable biomass. Dwarf shrub heath and bog vegetation are the most sensitive to stocking rate, but grassy heath and riverine vegetation are the most responsive to climatic scenario. Búmodel results should not be relied upon once extensive failures start occurring in the grazing simulations. These simulations are operating beyond the limits of the data that was used to parameterise the model, and there is no way of validating the results produced in this way. It should also be noted that grazing damage can occur below these failure thresholds, and land can be considered unsuitable for grazing, even though not all of the utilisable biomass has been consumed.

\subsection{Validation against existing, independent data sets}

Predictive validation of Búmodel was undertaken using published experimental data from a highland range, Auðkúluheiði, in northern central Iceland (Magnússon and Magnússon, 1992; Jónsdóttir, 1994). The experimental site is approximately $470 \mathrm{~m}$ above sea level and is a hummocky heath with mosses, dwarf shrubs and grasses. Three plots, with light (L), medium

(M) and heavy $(\mathrm{H})$ grazing pressures, were used in the experiment. The same stocking rate of 0.28 ewes ha ${ }^{-1}$ was used in each plot, but differences in biomass due to previous stocking treatments created the different grazing pressures.

The experimental plots were represented in Búmodel using a combination of dwarf shrub heath, moss heath and bare ground, as deduced from the coverage of plant types and the botanical species composition. The vegetated area in $L$ was estimated as being composed of

3:1 dwarf shrub heath to moss heath, that in $M$ as 2:1, and the vegetated area in $\mathrm{H}$ as being composed of equal areas of dwarf shrub heath and moss heath. The cold climatic scenario and northern location were used in the model simulations. The other model input parameters are given in Table 6.

A run of 20 simulations was undertaken for each grazing pressure experiment. The Auðkúluheiði experiment ran from 13th July to 13th 
September so the livestock distribution sub-model was set up so that the sheep grazed the upland in these months only. Results given in Jónsdóttir (1994) allow the comparison of the

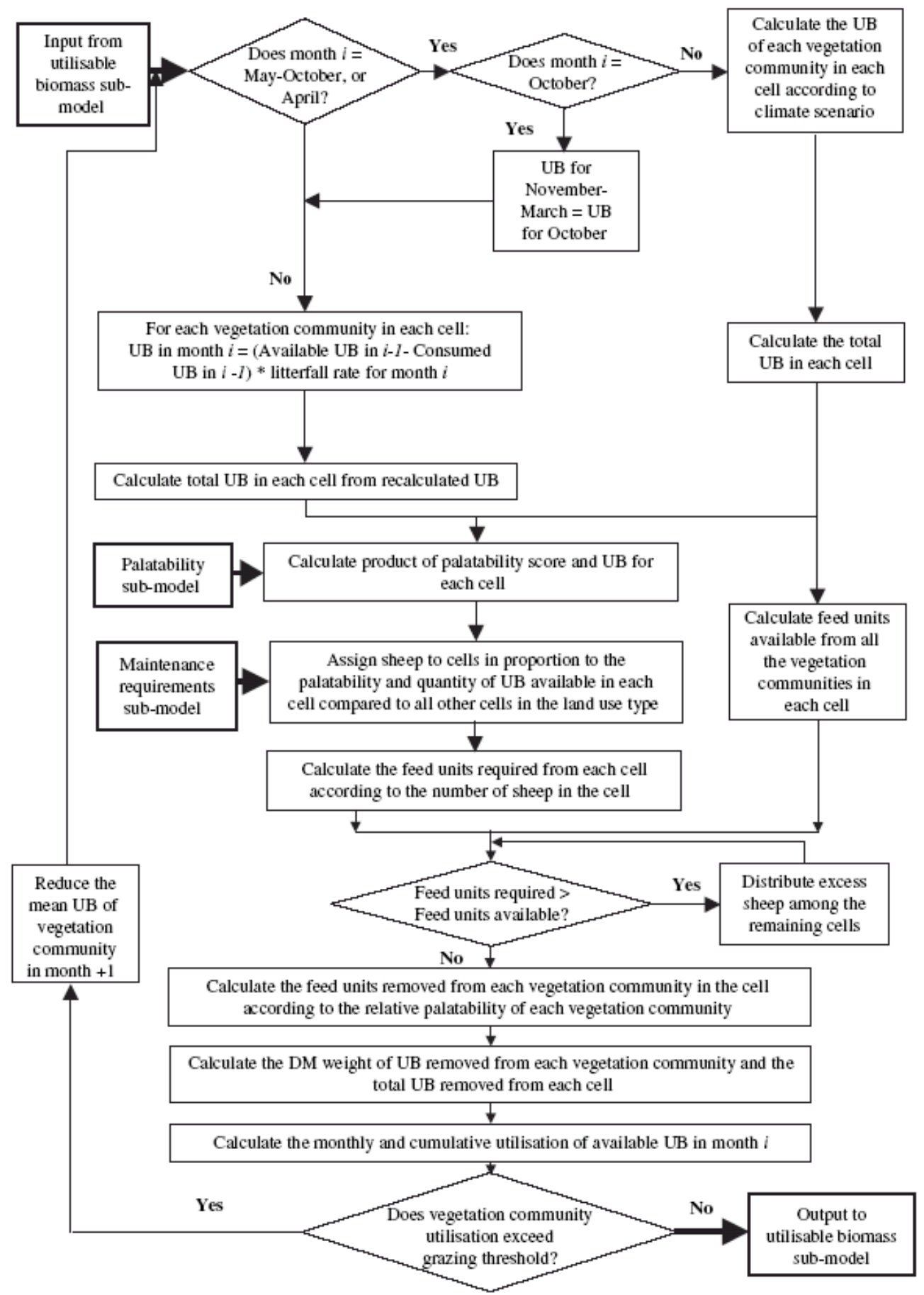

Fig. 8. The structure of the production-offtake feedback sub-model. 
observed and predicted values of utilisable biomass and dry matter intake (a proxy for offtake).

\subsection{Validation results}

The experimental versus the predicted biomass values are shown in Fig. 9. In general the observed mean biomass values fall within G1 standard deviation of the predicted mean biomass. Even when the observed values fall outside the range of standard deviation, they still fall (with one exception) within the predicted maximum and minimum values. Essentially the model predictions fit the observed biomass values well because the variability built into the model is supposed to produce a range of results, and the observed values fall within that range.

The mismatch between the predicted and observed biomass in the $L$ plot in early July seems to be related to previous grazing management, resulting in large amounts of standing biomass being carried through from the previous year's growth. In all three plots the model overestimates biomass in the later part of the experiment. This may be due to the reported wet weather

Table 6 Area, stocking numbers and weights of each experimental plot at Auðkúluheiði

\begin{tabular}{llrlll}
\hline Plot & Area (ha) & Ewes & $\begin{array}{l}\text { Initial weight } \\
\text { of ewes }(\mathrm{kg})\end{array}$ & Lambs & $\begin{array}{l}\text { Initial weight of } \\
\text { lambs }(\mathrm{kg})\end{array}$ \\
\hline Light & 54 & 15 & $59.2 \pm 6.27$ & 29 & $14.9 \pm 2.37$ \\
Medium & 36 & 10 & $59.8 \pm 4.86$ & 20 & $14.8 \pm 3.16$ \\
Heavy & 18 & 5 & $59.3 \pm 4.22$ & 10 & $14.6 \pm 1.51$ \\
\hline
\end{tabular}

in the summer of 1989 affecting growth; or it may be because Auðkúluheiði, being at high elevation and experiencing a relatively 'continental' climate, has an unusually short growing season, whereas Búmodel was built using data from mainly lowland sites, with longer growing seasons. If so, the inclusion of precipitation and 'continentality' as climatic parameters should be considered as priorities in the future development of Búmodel.

The observed dry matter intake (grams of dry matter consumed per head of livestock per day) was taken as a proxy for model offtake (kilograms of dry matter removed per month). In the experiment this was measured over three periods (13th-31st July, $1^{\text {st }}$-21st August, and 22nd August-13th September) for livestock on the Light and Heavy plots. These measurements were compared to the corresponding mean offtake per head per day for the months of July, August and September (Fig. 10). Búmodel predicts dry matter intake well, as the observed mean value falls within one standard deviation of the model mean value for all but one of the periods. Búmodel also correctly predicts the August peak, and the lower intake on the lightly grazed plot. T-tests comparing the observed and predicted values found no significant difference between the two data sets on both the Light ( $T$-value $=0.15, \mathrm{p}=0.893, \mathrm{df}=2$ ) and the Heavy plots ( $\mathrm{T}$-value $=1.22, \mathrm{p}=0.347 \mathrm{df}$ $=2$ ). (However, the sample size was very small.) 
The monthly cumulative utilisation values predicted by Búmodel are given in Table 7. Given the high proportion of dwarf shrub heath in the experimental area, it would appear that all three plots are at risk of being overgrazed (as the September cumulative utilisation values are above the threshold value of $15 \%$ ). Jónsdóttir (1994) also concluded that stocking was too high in both the $\mathrm{M}$ and $\mathrm{H}$ plots, and that the optimum stocking rate was closer to that in plot L. She suggested that grazing on the experimental area started too early in the summer of 1989, reducing the length of productive grazing in the later part of the grazing season.

\section{Discussion and conclusion}

\subsection{Overview}

The objective in constructing Búmodel was to provide a validated representation of the quantifiable linkages between different environmental and management elements in a historical grazing system, predicting vegetation biomass production and offtake by livestock across a landscape in space and time. The model has been able to include vegetation cover, land use categories, climate scenarios, flock size and composition, livestock body weight and distribution as input parameters. These inputs feed into the process sub-models of maintenance requirements, vegetation palatability and plant preferences of livestock, and the production of hay and grazeable biomass. The model has been validated for its intended historical I celandic context. 


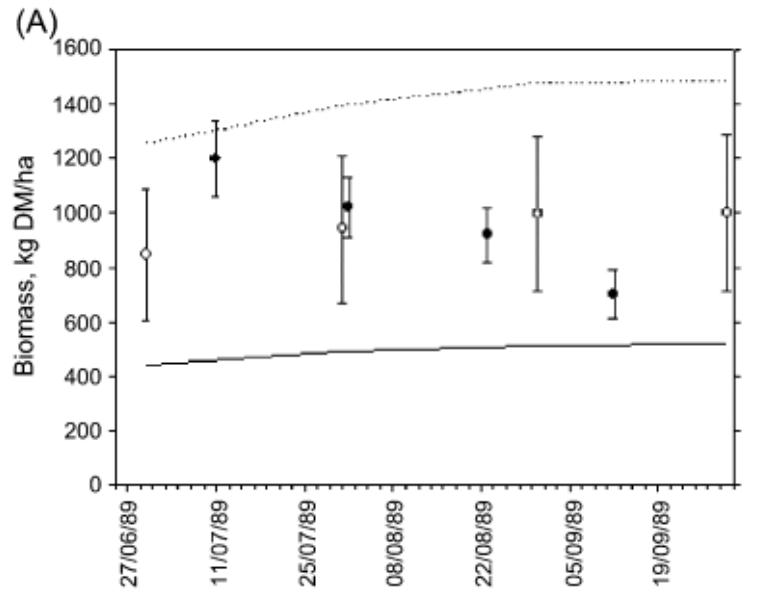

(B)
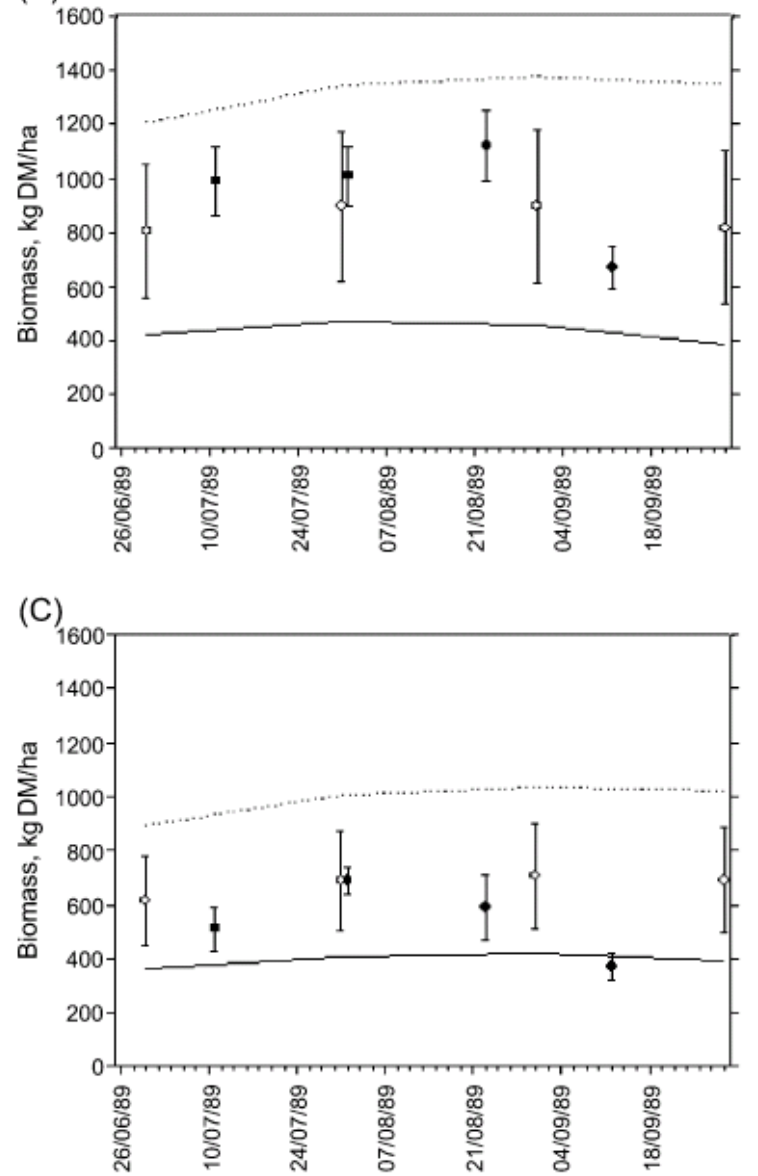

- Obeserved mean, with St. Dev.

- Predicted mean, with St. Dev.

Predicted minimum

. Predicted maximum

Fig. 9. Observed vs. Búmodel-predicted utilisable biomass on the (A) Light, (B) Medium, and (C) Heavy grazed plot. 


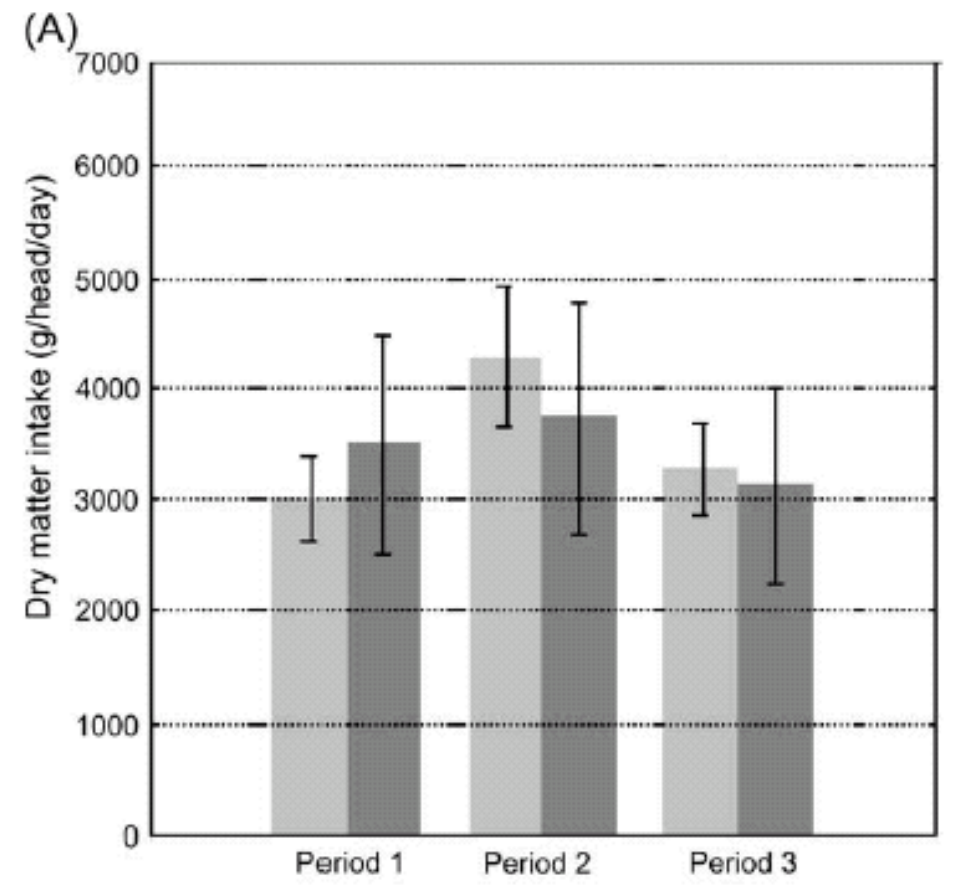

(B)

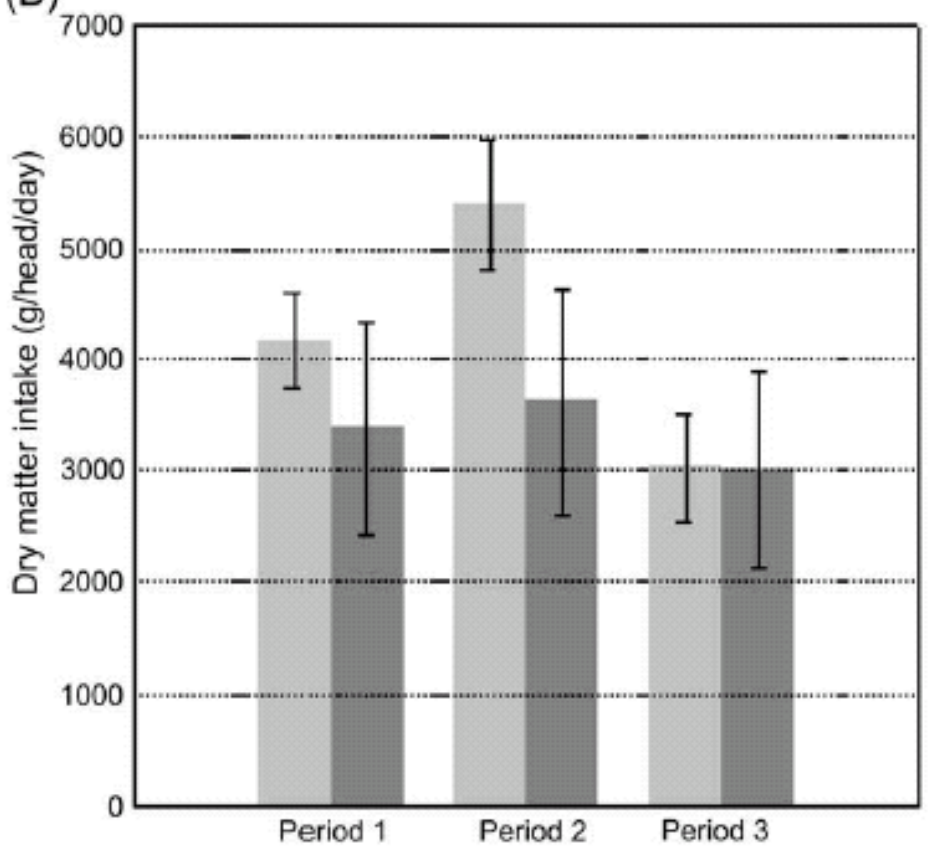

Observed mean, with St. dev.

Búnmodel predicted mean, with St. Dev.

Fig. 10. Observed vs. Búmodel-predicted dry matter intake on the (A) Light, (B) Medium, and (C) Heavy grazed plot 
Table 7 Búmodel-predicted cumulative utilisation, \%, on the experimental plots at Auðkúluheiði

\begin{tabular}{lrll}
\hline & \multicolumn{1}{c}{ July } & August & September \\
\hline Light & $9.0 \pm 1.5$ & $18.6 \pm 2.9$ & $26.4 \pm 4.2$ \\
Medium & $10.4 \pm 2.5$ & $21.7 \pm 5.1$ & $30.8 \pm 7.3$ \\
Heavy & $12.5 \pm 2.3$ & $25.8 \pm 4.7$ & $36.5 \pm 6.5$ \\
\hline
\end{tabular}

Validation testing indicates that Búmodel mimics the Icelandic grazing system well, with the observed mean values of utilisable biomass and dry matter intake falling within one standard deviation of the predicted mean values.

\subsection{Model critique}

As it stands, Búmodel is a simple environmental simulation model of the I celandic grazing system. The dependence upon linear models reflects the published research and the limited number and size of data sets that are available to work from, a common problem in the sub-polar regions.

The influence of climate on vegetation growth is described in terms of scenarios based on mean temperature curves, ignoring the possible influence of precipitation, which may be equally important in certain regions. The influence of elevation and latitude on vegetation is assumed to affect the distribution of vegetation categories rather than having a direct impact on production. Only sheep are considered in the livestock parameters, which is a shortcoming in Búmodel's representation of the grazing system. The inclusion of cattle would extend the scope of the model, and allow consideration of inter-species interactions in grazing patterns.

Improvements could be made to the statistical outputs generated by the model, for example, by examination of the 5 and 95 percentile values rather than the maximum and minimum values. This would require a greater number of runs to be undertaken, as the sets of 20 runs used for model assessment was the minimum required for quasi-stable results.

Specific issues relevant to historical environmental simulation modelling have emerged in the design of Búmodel, and require detailed consideration in historical modelling. It is evident that the data used in model construction and calibration must be relevant in spatial and temporal scale to the grazing system under investigation. For example, vegetation cover can be reconstructed at the broad vegetation community level ( $>1$ ha) using palaeoecology but it is not justifiable to refine this reconstruction to the level of vegetation associations (0.01-1 ha). We also note that in using data from a wide range of sources a rigorous assessment of data quality is necessary; this was achieved on an expert advice basis. Consistency of quality is, in historical modelling, more important than using the most precise data available, when such availability is patchy. Furthermore, it is important that sources of all data are stated clearly as well as the assumptions in its usage. Historical environmental simulation models are required to incorporate the inherent variability of natural and managed systems and this is a key aspect 
of Búmodel design, recognising that similar management and environmental inputs can result in multiple outcomes. The ability to examine the range of possible outcomes, including extreme scenarios, is essential when alternative historical management practices are being considered.

\subsection{Further applications}

Búmodel will enable researchers interested in historical land management to investigate the flexibility of the historical Icelandic agricultural system given the limitations of climate and vegetation cover. It provides an environmental science-based counterpoint to the work by Daniel Vasey in I celand on human buffering mechanisms (Vasey, 1996). Búmodel has been applied in Iceland to examine grazing management and landscape impact in the post-settlement and 18th century periods (Thomson and Simpson, in press), and is being used to look at similar questions in the Faeroe Islands. The model enables the testing of ideas of historical contingency ewere the historical outcomes that are visible in the landscape and in the archaeological record (such as farm abandonment, vegetation change and soil erosion) inevitable given the environmental and social constraints in the past, or were they avoidable? The methodology we have used in constructing Búmodel offers a way of synthesising the available information for a landscape, combining spatial and temporal perspectives, and will enable a broader view of past human eenvironmental interaction.

\section{Acknowledgements}

We gratefully acknowledge the support of the Icelandic Agricultural Research Institute (RALA) in making data sets available to us and for valuable discussions. Specific thanks are due to Siggi Jónsdóttir (Soil Conservation Service of Iceland), Orri Ve' steinsson (Institute of Archaeology, Iceland) and Tom McGovern (City University of New York). The project was supported by the University of Stirling, the National Science Foundation and the Leverhulme Trust. 


\section{References}

Amorosi, T., Buckland, P.C., Edwards, K.J., Mainland, I., McGovern, T.H., Sadler, J.P., Skidmore, P., 1998. They did not live by grass alone: the politics and palaeoecology of animal fodder in the North Atlantic region. Environmental Archaeology 1, 41-54.

Archer, S., Tiezen, L.L., 1980. Growth and physiological responses of tundra plants to defoliation. Arctic and Alpine Research 12, 531-552.

Archibold, O.W., 1994. Ecology of World Vegetation. Chapman and Hall, London.

Armstrong, H.M., Gordon, I.J., Grant, S.A., Hutchings, N.J., Milne, J.A., Sibbald, A.R., 1997a. A model of the grazing of hill vegetation by sheep in the UK I: the prediction of vegetation biomass. Journal of Applied Ecology 34, 166-185.

Armstrong, H.M., Gordon, I.J., Hutchings, N.J., Illius, A.W., Milne, J.A., Sibbald, A.R., 1997b. A model of the grazing of hill vegetation by sheep in the UK II: the prediction of offtake by sheep. Journal of Applied Ecology 34, 186-207.

Arnalds, O, Aradóttir, A.L., Thorsteinsson, I., 1987. The nature and restoration of denuded areas in Iceland. Arctic and Alpine Research 19, 518-525.

Arnalds, O., porainsdóttir, E.F., Metusalemsson, S., Jonsson, A., Gretarsson, E., Arnason, A., 2001. Soil Erosion in Iceland. Soil Conservation Service, Agricultural Research Institute, Reykjavík, I celand.

Arnold, G.W., Dudzinski, M.L., 1978. The Ethology of Free-ranging Domestic Animals. Elsevier, Oxford.

Bergpórsson, P., Bjo" rnsson, H., Dýrmundsson, O, Gudmundsson, B., Helgadóttir, A., Jónmundsson, J.V., 1987. The effect of climatic variations on agriculture in Iceland. In: Parry, M.L., Carter, T.R., Konijn, N.T. (Eds.), The Impact of Climatic Variations on Agriculture. IIASA and UNEP, Dordrecht.

Blaikie, P., Brookfield, H., 1987. Land Degradation and Society. Methuen, London.

Buckland, P.C., Dugmore, A.J., Perry, D.W., Savory, D., Sveinbjarnardóttir, G., 1991. Holt in Eyjafjallasveit, Iceland: a paleoecological study of the impact of Landna' m. Acta Archaeologica 61, 252-270.

Foy, J.K., Teague, W.K., Hanson, J.D., 1999. evaluation of the upgraded SPUR model (SPUR2.4). Ecological Modelling 118, 149-165.

Fridriksson, S., 1975. Surtsey. Evolution of Life on a Volcanic Island. Butterworths, London.

Friðriksson, S., 1972. Grass and grass utilization in Iceland. Ecology 53, 785-796.

Friðriksson, S., Sigurðsson, F.H., 1983. The effect of air temperature on grass growth. Islenzkar Landbúnaðarrannsóknir 15, 41-54.

Gísladóttir, G., 1998. Environmental characterisation and change in south- 
west I celand. PhD thesis, Stockholm University.

Grant, S.A., Lamb, W.I.C., Kerr, C.D., Bolton, G.R., 1976. The utilization of blanket bog vegetation by grazing sheep. Journal of Applied Ecology 13, 857-869.

Gross, J.E., McAllister, R.R.J., Stafford Smith, M., Abel, N., Maru, Y., 2003. Australian Rangelands as complex adaptive systems: a conceptual model \& preliminary results. In: MODSIM2003 Conference. Townsville 14-17 July. http://www.cse.csiro.au/research/cabm/ GrossMcAllisterEtal Modsim2003.pdf

Guðmundsson, O., 1991. Evaluation of feed energy in relation to grazing livestock. Norwegian J ournal of Agricultural Sciences Suppl. 5, 17-35.

Hahn, B.D., Richardson, F.D., Hoffman, M.T., Roberts, R., Todd, S.W., Carrick, P.J., 2005. A simulation model of long-term climate, livestock and vegetation interactions on communal rangelands in the semi-arid Succulent Karoo, Namaqualand, South Africa. Ecological Modelling 183, 211-230.

Hajkowicz, S., Perraud, J.M., Dawes, W., DeRose, R., 2005. The strategic landscape investment model: a tool for mapping optimal environmental expenditure. Environmental Modelling and Software 20, 1251-1262.

Hallsdóttir, M., 1987. Pollen analytical studies of human influence on vegetation in relation to the Landna' $m$ tephra layer in southwestern Iceland. PhD thesis, Lund University.

Hill, M.J., Braaten, R., McKeon, G.M., 2003. A scenario calculator for effects of grazing land management on carbon stocks in Australian rangelands. Environmental Modelling and Software 18, 627-644.

Hill, M.J., Braaten, R., Veitch, S.M., Lees, B.G., Sharma, S., 2005. Multicriteria decision analysis in spatial decision support: the ASSESS analytic hierarchy process and the role of quantitative methods and spatially explicit analysis. Environmental Modelling and Software 20, 955-976.

Icelandic Meteorological Office, 2001. Research and processing: Icelandic climate data. !http://www.vedur.is/english/index_eng.html.

Jónsdóttir, S., 1994. Foraging activity and sheep performance and its relevance for range management in northern Iceland. MSc thesis, University College of North Wales.

Magnússon, B., Elmarsdóttir, A., Barkarson, B., 1998. Hrossahagar: horse ranges in I celand. http://www.rala.is/umhvd/hhagar.

Magnússon, B., Elmarsdóttir, A., Barkarson, B., Maronsson, B., 1999. Langtímamælingar og eftirlit í hrossaho" gum. (History and control of horse grazing).

http: // www. rala. is/radunautafundir.

Magnússon, B., Magnússon, S.H., 1992. Vegetation and plant preferences of sheep in a grazing trial on an alpine heathland range in northern Iceland. RALA Report 159. Agricultural Research Institute, Reykjavík, I celand. 
Magnússon, S.H., Magnússon, B., 1990. Studies in the grazing of a drained lowland fen in Iceland. II. Plant preferences of horses during summer. Búvísindi 4, 109-124. Melville, E.G.K., 1998. Cultural persistence and environmental change: the Otomí of the Valle del Mezquital, Mexico. In: Bale' e, W. (Ed.), Advances in Historical Ecology. Columbia University Press, New York.

Merritt, W.S., Croke, B.F.W., Jakeman, A.J., 2005. Sensitivity testing of a model for exploring water resources utilisation and management options. Environmental Modelling and Software 20, 1013-1030.

Netting, R., 1996. What alpine peasants have in common: observations on communal tenure in a Swiss village. In: Bates, D.G., Lees, S.H. (Eds.), Case Studies in Human Ecology. Plenum Press, New York.

Ogilvie, A.E.J., 1984a. The impact of climate on grass growth and hay yield in Iceland: A.D. 1601 to 1780. In: Mo“" rner, N.A., Karle' n, W. (Eds.), Climatic Changes on a Yearly to Millennial Basis: Geological, Historical, and Instrumental Records. Reidel, Dordrecht.

Ogilvie, A., 1984b. The past climate and sea-ice record from Iceland, part 1: data to AD 1780. Climatic Change 6, 131-152.

Olafsdóttir, R., Guðmundsson, H.J., 2002. Holocene land degradation and climatic change in northeastern I celand. The Holocene 12, 159-167.

Olafsson, G., 1980. The nutritive value of range plants. I slenzkar Landbúnaðarrannsóknir 12, 127-134.

Olafsson, G., 1973. The plant preference of grazing sheep in Iceland. I slenzkar Landbúnaðarrannsóknir 5, 3-63.

Pickup, G., 1994. Modelling patterns of defoliation by grazing animals in rangelands. J ournal of Applied Ecology 31, 231-246.

Prock, S., Ko" rner, C., 1996. A cross-continental comparison of phenology, leaf dynamics and dry matter allocation in arctic and temperate zone herbaceous plants from contrasting altitudes. Ecological Bulletins 45, 93 e103.

RALA, 1978a. Utilisation and conservation of grasslands. Progress report 1976. RALA Report no. 29. Agricultural Research Institute, Reykjavík, I celand.

RALA, 1978b. Utilisation and conservation of grasslands. Progress report 1977. RALA Report no. 38. Agricultural Research Institute, Reykjavík, Iceland.

RALA, 1979. Utilisation and conservation of grasslands. Progress report 1978. RALA Report no. 50. Agricultural Research Institute, Reykjavík, I celand.

RALA, 1980. Utilisation and conservation of grasslands. Progress report 1979. RALA Report no. 63. Agricultural Research Institute, Reykjavík, I celand.

RALA, 1981. Utilisation and conservation of grasslands. Progress report 1980. RALA Report no. 79. Agricultural Research Institute, Reykjavík, I celand.

Simpson, I.A., Adderley, W.P., Guðmundsson, G., Hallsdóttir, M.,

Sigurgeirsson, M.A., Snæsdóttir, M., 2002. Soil limitations to agrarian land 
production in premodern Iceland. Human Ecology 30, 423-443.

Simpson, I.A., Dugmore, A.J., Thomson, A., Ve' steinsson, O., 2001. Crossing the thresholds: human ecology and historical patterns of landscape degradation. Catena 42, 175-192.

Steindórsson, S., 1980. Vegetation classification in Iceland. Islenzkar Landbúnaðarrannsóknir 12, 11-52.

Thomson, A.M., 2003. A modelling approach to farm management and vegetation degradation in pre-modern Iceland. PhD thesis, University of Stirling. http://dspace.stir.ac.uk/dspace/handle/1893/23.

Thomson, A.M., Simpson, I.A. Modeling historic rangeland management and grazing pressures in landscapes of settlement. Human Ecology, in press.

Thórhallsdóttir, A.G., Thorsteinsson, I., 1993. Behaviour and plant selection. Búvísindi 7, 59-77.

Thorsteinsson, I., 1980a. Environmental data, botanical composition and production of plant communities and the plant preference of sheep. Islenzkar Landbúnaðarrannsóknir 12, 85-99.

Thorsteinsson, I., 1980b. Grazing intensity eproper use of rangelands. I slenzkar Landbúnaðarrannsóknir 12, 113-122.

Thorsteinsson, I., 1980c. The grazing value of plant communities. Islenzkar Landbúnaðarrannsóknir 12, 123-125.

Thorsteinsson, I., 1964. Studies on the plant preferences of sheep. Freyr 11, 194-201.

Thorsteinsson, I., Arnalds, O., 1992. The vegetation and soils of the Thingvallavatn area. Oikos 64, 105e116. Thorsteinsson, I., Olafsson, G., 1967. Plant preference of sheep in open rangeland and reforested area. Arsrit Skógræktarfe' lags Islands 1967, 6-14.

Thorsteinsson, S.S., Thorgeirsson, S., 1989. Winterfeeding, housing and management. In: Dýrmundsson, O., Thorgeirsson, S. (Eds.), Reproduction, Growth and Nutrition in Sheep. Agricultural Research Institute and Agricultural Society, Reykjavík, pp. 113-146.

Vasey, D., 1996. Population regulation, ecology, and political economy in medieval Iceland. American Ethnologist 23, 366e392. porarinsson, S., 1944. Tefrokronoliska studier pa ${ }^{\circ}$ I sland. Geografiska Annaler 26, 1-217. 